\title{
A Method for Simulation of Upward Root Growth Pressure in Compacted Sand
}

\author{
Jason C. Grabosky and Nenad Gucunski
}

\begin{abstract}
In order to model the impacts of tree root growth under pavement as a layered design, the behavior of the components need to be defined or assumed. Since the behavior of materials and the design of pavement sections work on the presumption of loading from the pavement surface downward, it is reasonable to check engineering behavior assumptions with a testing method for controlled loading upward from a growing perennial root. A root simulation was developed to inflate with water to known input pressure. Sand displacement in response to increasing input pressure was tracked over several sand density-moisture level pairings. Load cells tracked the translation of sand displacement to load at a simulated pavement surface to develop data plots of a line-load spreading wider with increasing distance between root and pavement. The results from the laboratory experiments were compared to the results from numerical simulations using finite elements to develop better understanding of the mechanisms of load generation due to the root growth. Sand was modeled as a Mohr-Coulomb type material for that purpose. The numerical results are qualitatively in agreement with the experimental results.

Key Words. Compaction; Pavement; Root.
\end{abstract}

Successful urban forest management benefits from quality urban design. To be sustainable, urban design suggests multiple uses from shared but limited resources and spaces. As soil space is a limited commodity in heavily urbanized places, soil volumes and open soil surface areas are needed for transportation, pedestrian use, stormwater management, and vegetation zones.

Designed soil materials (DSMs) have been developed as a soil replacement strategy to support tree growth in or adjacent to paved areas to establish urban canopy (Costello and Jones 2003). There is interest in combinations of tree canopy and various porous pavements in the design of parking lots to address stormwater management issues and to meet tree ordinance requirements (Scott et al. 1999; McPherson et al. 2001; Swiecki and Bernhardt 2001; Bartens et al. 2008; Day and Dickinson 2008). The increasing usage and continued testing of DSMs over the past decade has suggested the ability to integrate stormwater management strategies, urban tree canopy establishment, and pavement surface in one shared soil volume (Smiley et al. 2006; Bühler et al. 2007; Day and Dickinson 2008; Grabosky and Bassuk 2008; Rahardjo et al. 2008; Grabosky et al. 2009). The use of DSMs assumes the ability to support the pavement wearing surface. Standard testing methods to estimate load bearing and other physical behaviors have been used as a framework for DSM mix design (Grabosky et al. 1996; Rahardjo et al. 2008). If roots are encouraged to grow below pavement through usage of DSMs, then methods to quantify long-term radial root growth effects on the service life of the wearing surface are needed. To date, none of the DSM systems have explicitly addressed the natural consequence of root growth in general design practice.

The long-term consequences of root growth under pavement need to be systematically described to provide an integrated de- sign approach for both pavement and tree. A finite element method (FEM) approach could be useful as an inexpensive method to simulate root-pavement systems. In the FEM, the pavement section layers are defined by depth and engineering behaviors based on constitutive models and associated parameters. Once such parameters are defined, the region is discretized into a mesh consisting of elements and nodes based on the behavior of each layer in the pavement section detail. A digital root model that increases in size can be used to test pavement system response to a load or a displacement simulation to test layer thicknesses and root positions in the development of cracks in a pavement surface.

Pavement sections consider loading from above by defined traffic usage (National Cooperative Highway Research Program 1993) as supported through subtending material layers. The perennial growth of a large woody root within the section could be considered as a permanent displacement or a cavity expansion within the profile presenting an upward rather than a supported downward force. Assumptions for upward loading on pavement layer behavior and the appropriate geometry ought to be challenged or verified prior to use in a root growth simulation as an upward-loading model. Once in place, FEMs could be developed to simulate effects of single roots and multiple roots and variable layer thicknesses. A validated model could then be adjusted to evaluate or refine root protection strategies and design methods, once root growth and section design parameters are better defined. The first step would be to design a system to simulate root growth under pavement to test assumptions and describe expected behaviors with empirical data.

To define the geometry for building a test system for a laboratory simulation, the study authors based a first approximation on existing soil mechanics theory in pavement design and scaled the 
box between 1:1 and 1:2 depth to width ratios (in example, Cheng et al. 2004 and Chiroux et al. 2005). Westergaard (1926) defined the force required per unit soil deflection as the modulus of subgrade reaction with regard to pavement deflections in a layered design as one aspect of soil layer evaluation and behavior. Still used today, the physical characteristics of soil, including texture, density, and moisture content, influence the soil behavior under load (National Cooperative Highway Research Program 1993). There have been a number of simplified models used to describe load transfer in pavement and soil systems. For example, in U.S. pavement design practice in the 1940s, a live load transmitted freely to a subgrade was commonly assumed to radiate downward as a truncated cone with line elements of 45 degrees, or a 1:1 slope (Hewes 1942). Viewed in the reverse direction, a root of 1 unit diameter, placed 6 units below the pavement, would spread over 13 units at the pavement. Given the likely differences in lifting soil upward against a pavement surface, rather than displacing soil outward or downward, the 1:1 slope can serve as guidance rather than a given dimension. It is common to roughly estimate the distribution of vertical stress through soil depth using a 2:1 slope method across the distance of a rectilinear object as a convenient first approximation (Holtz and Kovacs 1981). However, all of those models were developed assuming purely elastic deformation, and thus might have limited applicability to the root growth problems where the plastic soil deformation is significantly present. More complex curvilinear distributions can be approximated using other methods with limiting assumptions regarding the soil in place (Liingaard et al. 2004).

Roots cannot be assumed to impose loads in the same geometric pattern, speed of load increase, or over the same time period as traditional loading pattern in pavement design. A root segment can be modeled as a rectilinear object for a first approximation. The testing system was thus designed to collect data over a $72 \mathrm{~cm}$ wide area for a $2.54 \mathrm{~cm}$ root at $15 \mathrm{~cm}$ maximum depth, or roughly twice the expected testing surface.

This paper describes a root growth laboratory simulation method to induce displacement within a sand system to measure the force distribution on a pavement surface. The method could test strategies in use to protect pavement from root growth with a standardized protocol for comparative evaluation and design guidance. A simple study will describe sand displacement in response to increasing input pressures. The current study includes examples of load profiles captured at the surface as it changes with sand layer depth as an example of the simulation method's use. In this case, it was used to describe load profiles with changing moisture and density when the sand was displaced from increasing root size.

\section{MATERIALS AND METHODS}

\section{The Simulation Method}

A liquid-filled rubber gasket (Giant brand bicycle inner tube with a $0.9 \mathrm{~mm}$ wall thickness) was housed in a milled aluminum holding block fabricated in the Rutgers Cook Campus Machine shop (New Brunswick, NJ, U.S.) (Figure 1). The rubber gasket was held in place by the upper-milled aluminum housing with a $2.54 \mathrm{~cm} \times 27.94 \mathrm{~cm}$ centered opening, to provide an initial inflation surface of $70.97 \mathrm{~cm}^{2}$. This apparatus, which will be referred to as the root, was designed to be filled with pressurized water. Volume changes with an in-line pressure rated graduated cylinder. Increasing pressure inputs within compacted sand profiles, were used to simulate upward radial root growth. Pressure to the root was generated by compressed air through a manifold (SoilMoisture Manifold system 0700CG23, Santa Barbara, CA, U.S.). As the water was pressurized, it was forced into the root placed within a compacted sand profile.

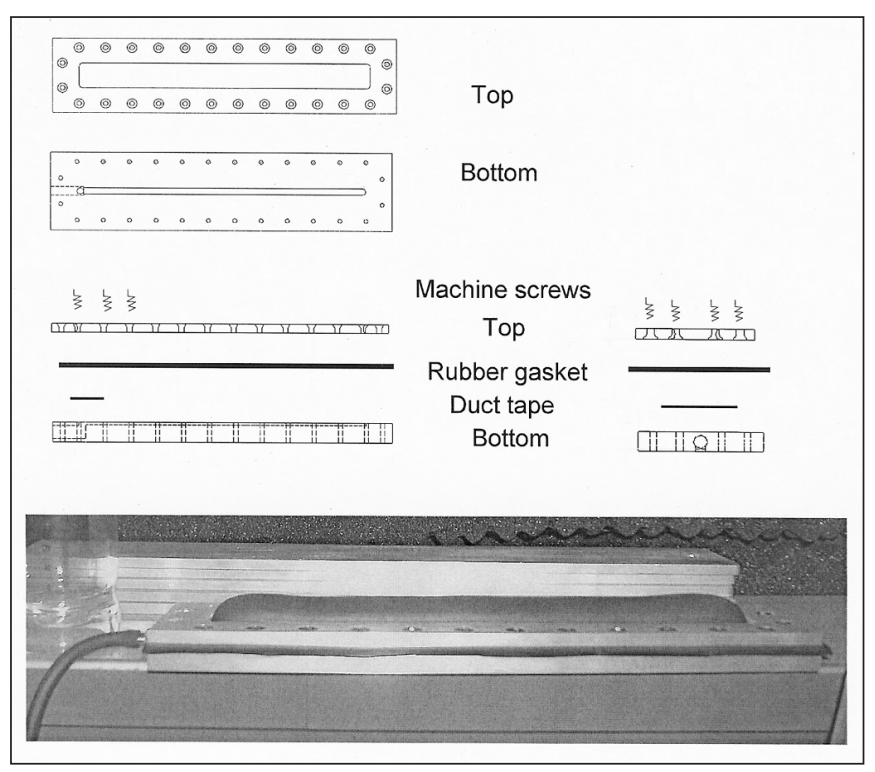

Figure 1. Schematic details of an inflatable rubber diaphragm to provide a laboratory simulation of a tree root. The image was adapted from AutoCad fabrication details (Cook agricultural engineering shop). Photo inset shows the "root" inflated at low pressure for demonstration purposes.

The root was placed into a custom-fabricated box (Rutgers Cook Campus Machine shop) of $37.15 \mathrm{~cm} \times 80.33 \mathrm{~cm} \times 2.54 \mathrm{~cm}$ $\left(7580 \mathrm{~cm}^{3}\right)$. Exterior threaded columns were used to attach and clamp a metal plate box top into place, with braces to prevent lifting and flexing of the box top. The box top served as the simulation of a pavement wearing surface layer (Figure 2). The box wall edges were milled to accept additional nesting wall sections of equal depth (lifts). To adjust the distance between the root (placed on the base) and the top of the box, lifts added $2.54 \mathrm{~cm}$ depth increments.

To map the load intercepted by the bottom surface of the box top resulting from sand displacement, a Novel Pliance Pedar pad (Novel Electronics, MN, U.S.) with a $16 \times 16$ grid of load cells was developed in a split pad layout to provide two pads containing load cell grids of $8 \times 16$ cells over an area of $24.8 \mathrm{~cm} \times 72 \mathrm{~cm}$. The pad fit into a milled recess in the box top to support the pad in a stable, consistent position. The pad was in direct contact with the sand once the box top was in place.

Data were taken at $38 \mathrm{~Hz}$ from load cells with a maximum reading of $60 \mathrm{Ncm}^{-2}\left(1 \mathrm{Ncm}^{-2}=10 \mathrm{kPa}\right)$ and processed through a Pliance signal conditioner (Novel Pliance Hw pad with Plaince$m 8.3$ standard sensor programming). Output from the entire load cell pad was labeled as a data frame ( 38 whole frames per second) and used to analyze the load distribution across the pad. Manifold-to-pad offsets as a calibration were developed to identify the influence of the initial recess of the rubber gasket in the root apparatus housing and its resistance to stretching (Figure 3). 
The milled position of the pad recess placed the pad over the expanding root while allowing the box top to be clamped without pre-loading the pad. The placement of the pad with respect to the root allowed collection of the spread in line load parallel to the root axis with one row of load cells directly over the root in a field of 16 load cell rows. This provided a working measurement zone of $33 \mathrm{~cm}$ to either side of the root (Figure 2 , bottom aspect ratios). There were eight columns of load cells (running perpendicular to the root length axis) which test the central portion of the root length to eliminate data collection from $1.5 \mathrm{~cm}$ at each root end (Figure 2, bottom aspect ratios).
Pressure was characterized as a mean value of each load cell in the pad ( 30 seconds at $38 \mathrm{~Hz}=1140$ data per load cell mean). Output from each load cell was in $\mathrm{N} \mathrm{cm}^{-2}$ and converted to $\mathrm{kPa}$. Measurement resolution was $10 \mathrm{kPa}$, when load was $\geq 100 \mathrm{kPa}$ and in increments of $1 \mathrm{kPa}$, when loads were below $100 \mathrm{kPa}$ within the entire data frame. Thus, the load cell output resolution in $\mathrm{N} \mathrm{cm}^{-2}$ is sensitive to input air pressure differences to the nearest $10 \mathrm{kPa}$ as read through the air manifold. Total range of an individual load cell signal within a stable manifold pressure input through the sand medium has been within one measurement unit of its mean. During calibration when the root was against the pad, there was zero signal variability. Load cell values, along any given row of eight load cells running parallel to the root axis, were averaged and used to produce a characteristic value as part of a line load at the box top for the input pressure data sets chosen. A series of row values were used to describe the width and intensity of the load resulting from the sand displacement perpendicular to the root axis. The values presented are representative load cell output means of the eight load cells. Output for a specific input pressure as captured over multiple tests for each testing depth is imposed onto a composite figure to show width and intensity of signal capture through the sand within the box at a specific distance between the root and the pad. Variability of reported values within a line of eight sensors was within two measurement units of the mean during any layer testing sequence.

The testing system design and method was based on the simplifying assumption that root pressure and behavior is homogenous over short distances and can be characterized as a point load or equivalently treated over a distance for line load. The direction of loading and displacement is assumed to be generally upward, given the lesser resistance to deformations in lifting overburden versus lateral and downward deformations in a compacted soil. Roots are also assumed to represent incrementally increasing permanent loads as they radially expand and harden in secondary growth over several years. Data collection is limited since testing cycle loads increase over seconds and minutes as opposed to years, while seasonal effects (such as wetting-drying or frost activity) and vibratory effects (assuming traffic on or near a paved surface) are lacking.
Figure 2. Schematic drawing of the testing system with diaphragm, box, root, and pad. The box was designed to accept nesting sidewalls to adjust the distance from "root" to a pressure mapping pad recessed in the box top. The lower insets provide aspect ratios between the "root" and the mapping pad. The top left photo shows the load cell pad recessed in the box top, while the right upper photo shows the testing box with five lifts over the root. The inlet for pressurized water is shown in the center of the base wall. The box top was marked with the load cell grid to track signals with relation to the root when testing was in progress. 


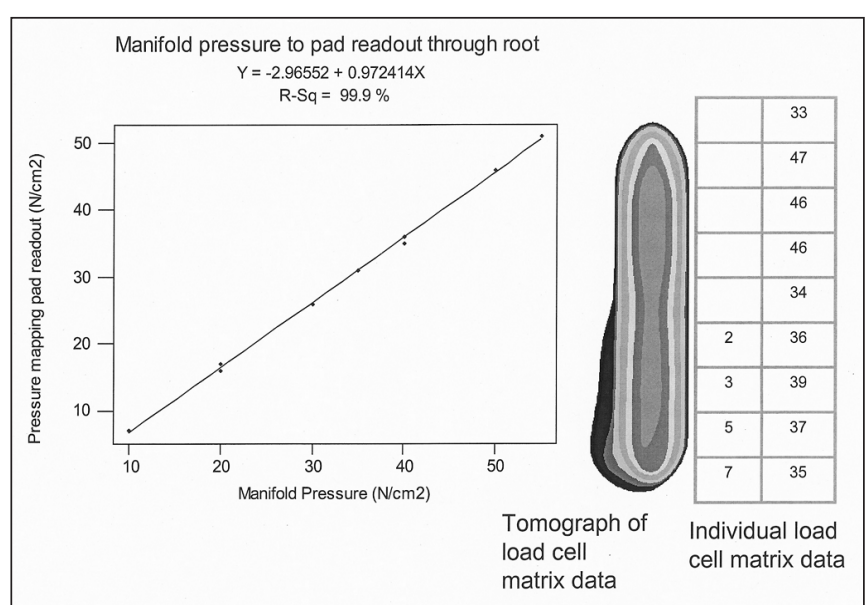

Figure 3. Example of a root calibration sequence that included a mapping signal regression between input manifold pressure and load cell output when the root was in direct contact with the load cell pad. The computer tomography and raw signal data used to create the tomograph and calibration regression relationships are shown at right of the calibration regression plot.

\section{Sand Displacement and Intercepted Load}

A poorly-graded, medium-fine sand (Unified Soil Classification system) was chosen as a representative base material (Figure 4) (American Society of Testing and Materials ASTM C-136-05). Testing occurred in sand at varied moisture content and density. Moisture levels were chosen to represent low, medium, and high moisture contents. The highest moisture content was limited to a level observed to be stable over the maximum testing depth of the sand during a multiple-hour testing sequence. The low sand moisture was defined as the delivered $0.08 \%$ gravimetric moisture. The sand was raised to $6 \%$ target gravimetric moisture level as a moderate moisture level and placed into sealed drums for mixing and holding. The maximum target moisture was determined by saturating hanging columns of compacted and noncompacted sand and allowing them to drain for 24 hours. A $12 \%$ gravimetric moisture level in the test sand was stable over 24

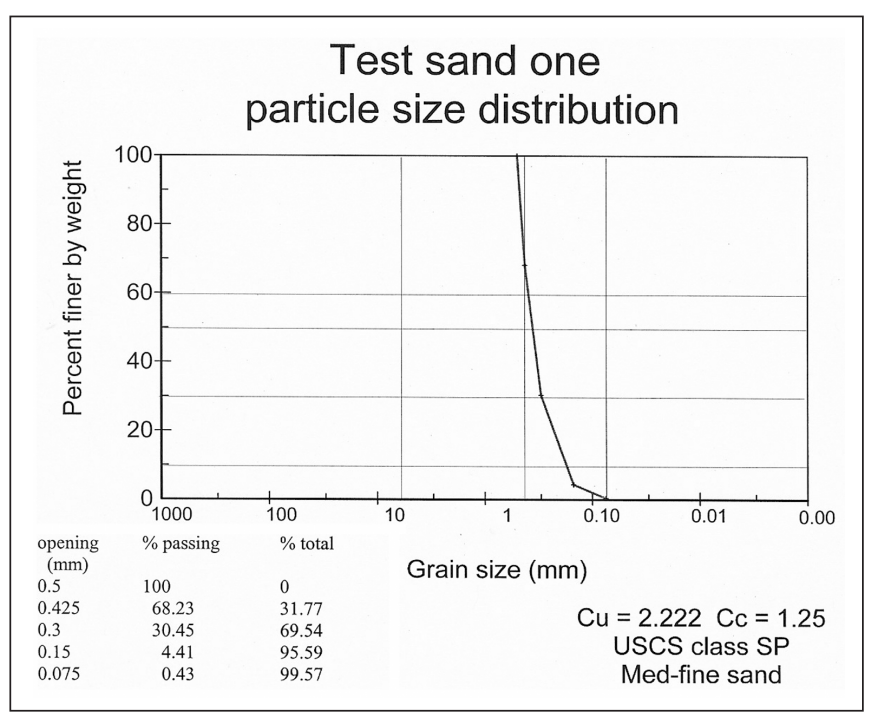

Figure 4. Characterization of the testing sand used in the example study, a USCS SP medium fine sand. hours at 30.48 and $15.24 \mathrm{~cm}$ elevation from a free-air interface, and thus used as a high level of moisture in the testing series.

Sand was mixed with water and verified to be the reported gravimetric moisture level. The moist sand was measured to target mass for the known test box volume and placed into the boxes. Sand was compacted with a $232 \mathrm{~cm}^{2}$ square metal plate hand tamper (compaction effort not calculated) to achieve the controlled sand moisture-density target for a given testing sequence, since the same density and moisture would be used for replicated tests on each of six lifts. The maximum testing density was defined by hand-compacting the dry sand to a point of no additional effect (dry density of $1.71 \mathrm{Mg} \mathrm{m}^{-3}$ ) in the box. A low placement density was set by lightly smoothing hand placed dry sand to level in the box $\left(1.51 \mathrm{Mg} \mathrm{m}^{-3}\right)$. The intermediate density was targeted for $1.61 \mathrm{Mg} \mathrm{m}^{-3}$, however slightly higher densities were tested as a consequence of adding sand for a uniform surface contact with the box top after screeding the top with a metal straightedge after compaction. After each testing sequence, the sand was loosened and re-compacted with the next lift of sand to remove any sand deformations or layer interfaces incurred from the previous test.

The data collection system was actuated at zero input pressure for 30 seconds. Input pressure was then increased over 15-40 seconds in $50 \mathrm{kPa}$ increments then held stable at each pressure level for a minimum of 30 seconds before raising to the next input pressure level. During the testing sequence, data frame numbers and associated times were tracked in the output files. To produce a combined output at each input pressure level for analysis, the data frames were parsed into separate analysis files as consecutive frame number sequences defined by timing logs of stable input pressure at the manifold. Water volume change in the graduated cylinder was noted to measure sand displacement at each pressure level. The water measure was also used to check for root failure as defined by leakage over a steady pressure interval.

After releasing the input pressure to the root at the end of a testing sequence to $0 \mathrm{kPa}$, the box was opened and the next successive lift was added to the box frame. The root was excavated by hand and checked for leakage. The excavated sand was replaced and slightly compacted prior to placing additional sand for the next lift. Once the next mass of sand was measured and added, it was compacted to the same target density level. This increased the distance between the root and the box top (representing the pavement surface layer) by $2.54 \mathrm{~cm}$. Plots for load cell readouts were developed for each pressure step and sand depth testing sequence. A series of plots at equal pressure input were combined to plot intercepted load distribution.

Data was collected up to $550 \mathrm{kPa}$. Input pressure - volume displacement curves were developed as best fit third order polynomials (Minitab 14.2 fitted line plot in regression analysis) for each moisture-density combination to show differences in yield. Displacement curves were fit with a third order polynomial to reflect a general sigmoidal pattern from each replicate test of increasing sand displacement with each increase of input pressure. Since standard testing of soil for strength and deformability plots pressure against cavity volume as a characteristic sigmoidal curve prior to analysis in Pressuremeter testing (Das 2004, ASTM D-4719), it was expected to behave in a similar manner for the different testing method which essentially tracks the same relationship in a different geometry. In all, five moisture-density pairings were tested using two rootbox systems. Duplicate tests were run to track test reliability. 
If a paired testing run showed very different behavior or leakage, the test was rejected and re-developed. Values shown in Figure 5 and Figure 6, for load cell readout, represent means of eight load cells values (1140 data per load cell with total variability of 1 measurement unit from recorded value) as detailed earlier.

Since related testing of root-induced foam deformation suggested a $0.40 \mathrm{MPa}$ as a minimum value for field-observed phenomena (Grabosky et al. 2011), and the same level was well within the testing range of the laboratory simulation system, the study authors chose the equivalent $400 \mathrm{kPa}$ input pressure analysis to present as an example, and for use in checking future FEM outputs against lab simulation behavior.

\section{RESULTS AND DISCUSSION}

Table 1 shows the best fit polynomial equations for data plots of sand displacement with increasing root inflation pressures. In general, the sand behavior was very consistent between testing runs, with increased variability with increased input pres- sures when sand moisture was increased. Variability relative to the input value was generally consistent as a ratio to imposed pressure. Figure $5 \mathrm{~b}$ (the most variable set) and Figure 6b (representative of the remaining four pairings) show best fit polynomial plots over multiple testing replicates for two of the five moisture-density pairings. Data series were not found to be related to the distance between root and box top. Using the 400 $\mathrm{kPa}$ input as an example (circled in Figures $5 \mathrm{~b}$ and Figure 6b), observed sand displacement volumes in this study were larger at lower densities when moisture was similar. Similarly, observed sand displacement volumes at $400 \mathrm{kPa}$ input did not increase as moisture content increased when the density was similar (Table 2). Observed sand displacements at $400 \mathrm{kPa}$ input were compared with expected values from the best fit polynomial model (Table 2). Sand deformation at the lowest tested density of $1.51 \mathrm{Mg} \mathrm{m}^{-3}$ exceeded the inflation volume capacity of the graduated cylinder. As a result, data collection for that density ceased at $350 \mathrm{kPa}$. The model outputs for the low density level are thus beyond the model observation and not reliable.
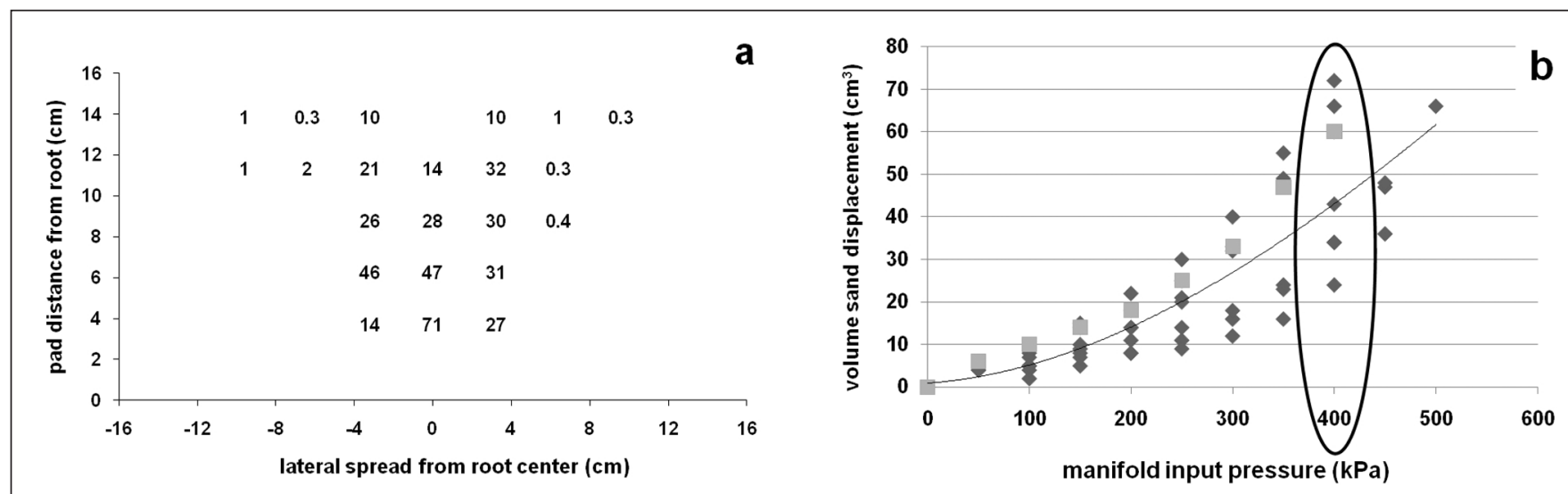

Figure 5. a) A data plot showing load cell mean output in a moderately compacted sand (1.63 $\left.\mathrm{Mg} \mathrm{m}^{-3}\right)$ at medium (6\%) gravimetric moisture. Mean sensor readout $(n=8)$ in $\mathrm{kPa}$ for line loads parallel to the inflating root at an inflation pressure of $400 \mathrm{kPa}$. Sensor readout developed from 30 second measurements collected at $38 \mathrm{~Hz}$. b) The associated pressure-yield curve with best-fit polynomial curve shown $y=$ $-0.0000001 x^{3}+0.000271 x^{2}+0.01662 x+0.916 R^{2}=0.76$. The circled values show displacements at $400 \mathrm{kPa}$ which link the load cell output to the pressure-yield curve data. Square data points show sigmoid character of an individual testing run.

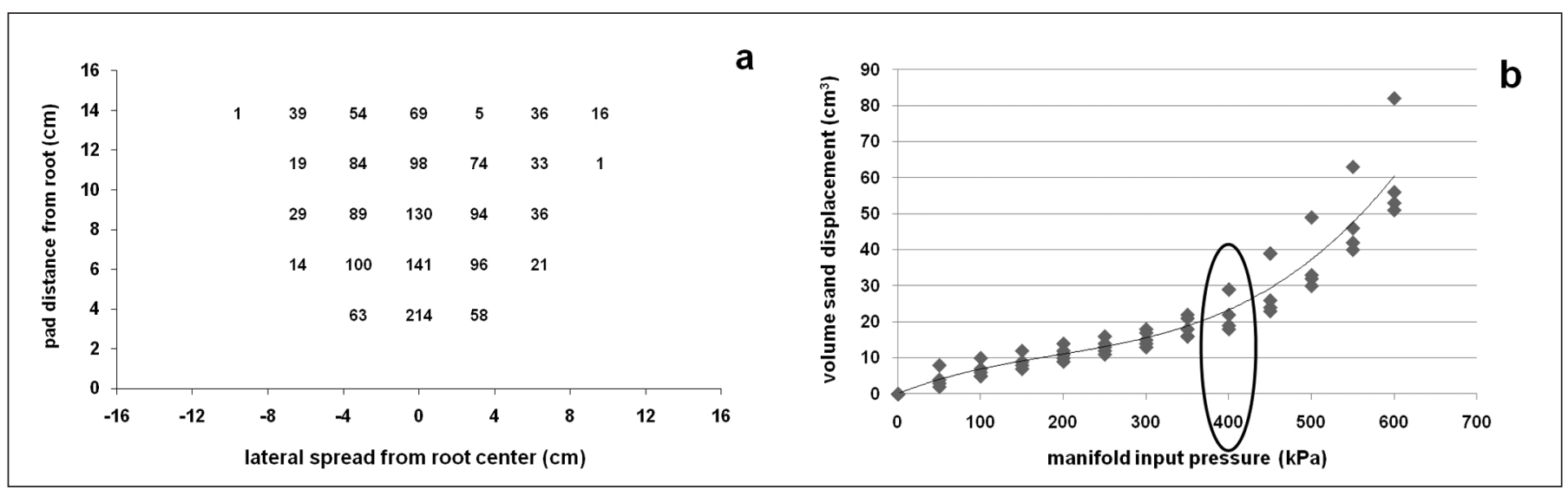

Figure 6. a) A data plot showing load cell mean output in a compacted sand $\left(1.71 \mathrm{Mg} \mathrm{m}^{-3}\right)$ at low $(0.08 \%)$ gravimetric moisture. Mean sensor readout $(n=8)$ in $\mathrm{kPa}$ for line loads parallel to the inflating root at an inflation pressure $400 \mathrm{kPa}$. Sensor readout developed from 30 second measurements collected at $38 \mathrm{~Hz}$. b) The associated pressure-yield curve with best-fit polynomial curve shown $y=0.0000005 x^{3}$ $-0.000279 x^{2}+0.09127 x+0.0386 R^{2}=0.91$. The circled values show displacements at $400 \mathrm{kPa}$, which link the load cell output to the pressure-yield curve data. 
Sand displacement translated into intercepted load at the box top. As moisture levels increased, intercepted load intensity decreased (Figure 5a; Figure 6a), relative to input pressure, despite a greater sand displacement. It is postulated that the load is confined to the sand aggregate contacts in the dry material. As the moisture increases, the contact continuity of the interstitial water within a non-saturated bulk system could dissipate the load.

The distribution of intercepted load across the pad was nonuniform across the widening line-load. This can be explained by plastic deformation in vicinity of the expanding root (cavity expansion). The problem is similar to the problem of tunnel construction, except that during the tunnel construction there will be reduction in the radial stress. Wood (2004) compared stress and displacement distributions during the tunnel construction for the assumption of elastic and elastic-plastic frictional ground. There, in the plastic zone, the radial and circumferential stresses were related through the Mohr-Coulomb criterion. In the case of an elastic material, the radial pressure increase will be linearly dependent on the radial displacement to cavity radius ratio change. In the case of an elasto-plastic material, it will be highly nonlinear as the displacement to cavity ratio increases. The load cell output plots could also reflect an elasto-plastic behavior that reduced its ability to transfer generated pressure at the cavity boundary in a linear fashion as the radial displacement increased. The data are consistent with the behavior of a granular soil such as the compacted sand against an over-arching stiffer layer (the braced box top) like a pavement surface layer. It has also been observed that stonesoil mixtures for use under pavement behave in the same manner (Rahardjo et al. 2008). The loading plots in Figure 5a and Figure 6a represent an experimental artifact since every layer depth in the plot was actually the sand surface placed against the load cell mat during its respective data capture, rather than an elevation within a deeper profile as the plot might suggest.

\section{CONCLUSIONS}

Modeling root growth displacement under pavement in layered section design can use existing assumptions for engineering behavior. If root systems can be encouraged to remain deep in the soil profile through designed systems, root loads can spread and overlap into a net movement upward from multiple roots. Such overlap might allow pavement to move without cracking from focused loading. Methods of protecting pavements by artificially spreading loads such as geotextile layers between the base and designed soil sub-bases could be evaluated to minimize loading into a layer-wide effect, thus alleviating line-load pavement lifting. The described testing system could be used to objectively evaluate such methods. Other pavement protection methods could also be evaluated against standard designs or other alternative methods in comparison for effectiveness.

The more difficult questions reside in defining the growth pressure/displacement capacity of large woody roots themselves. Issues would include the environmental factors influencing that growth potential, the confining resistance influencing eccentric root growth and characterizations of deformations from the typical root cross-sectional growth pattern. In generating stresses in a pavement surface layer, soil displacement from a growing root is the issue of importance. It is less important to define a maximum potential axial or radial growth pressure for defining growth impedance. The limiting input pressures of $550 \mathrm{kPa}-600 \mathrm{kPa}$ are satisfactory for a first approximation since sand displacement occurred. As models are developed for tree-pavement designs, it is hoped to use base layer thicknesses above designed root zone depths to prevent root growth pressures from damaging the pavement surface for a pavement design life in the range of 25-30 years. At that point, the pavement could be replaced without damage to the roots, if the roots are kept distant from the surface.

Table 1. Best fit polynomial regression pressure-displacement curves for a sand compacted to different densities at low (<1\%), medium (6\%), and high (12\%) gravimetric moisture content.

\begin{tabular}{|c|c|c|c|c|}
\hline $\begin{array}{l}\text { Sand } \\
\text { density } \\
\mathrm{Mg} \mathrm{m}^{-3}\end{array}$ & $\begin{array}{l}\text { Gravimetric } \\
\text { moisture }\end{array}$ & $\begin{array}{l}\text { Equation } \\
\mathrm{y}=\text { displacement volume }\left(\mathrm{cm}^{3}\right) \\
\mathrm{x}=\text { input pressure }(\mathrm{kPa})\end{array}$ & $\mathrm{R}^{2}$ & $\begin{array}{l}\text { Model } \\
\mathrm{p} \text { value }\end{array}$ \\
\hline 1.51 & $0.10 \%$ & $y=-0.0000047 x^{3}+0.002191 x^{2}+0.14722 x-0.0776$ & 0.86 & $<0.001$ \\
\hline 1.71 & $0.08 \%$ & $y=0.0000005 x^{3}-0.000279 x^{2}+0.09127 x+0.0386$ & 0.91 & $<0.001$ \\
\hline 1.64 & $0.10 \%$ & $y=0.0000003 x^{3}+0.00009 x^{2}+0.02973 x+0.6384$ & 0.97 & $<0.001$ \\
\hline 1.63 & $6.00 \%$ & $y=-0.0000001 x^{3}+0.000271 x^{2}+0.01662 x+0.916$ & 0.76 & $<0.001$ \\
\hline 1.67 & $12.00 \%$ & $y=0.0000008 x^{3}-0.000312 x^{2}+0.06401 x-0.3949$ & 0.92 & $<0.001$ \\
\hline
\end{tabular}

Table 2. Testing output versus the expected polynomial regression model sand displacements at input level $400 \mathrm{kPa}$. Low, medium, and high descriptors were used to distinguish intended treatment levels. $X X=$ Input level for density 1.51 that was limited to $350 \mathrm{kPa}$ since sand displacement volumes exceeded measurement capacity and are considered unreliable. Subscripts of different letter for testing output displacement were different at $\alpha=0.05$ in Oneway AOV. Testing output was consistent with model outputs in the $400 \mathrm{kPa}$ root inflation pressure.

\begin{tabular}{|c|c|c|c|}
\hline $\begin{array}{l}\text { Sand } \\
\text { Density } \\
\mathrm{Mg} \mathrm{m}^{-3}\end{array}$ & $\begin{array}{l}\text { Gravimetric } \\
\text { moisture }\end{array}$ & $\begin{array}{l}\text { Observed Displacement }\left(\mathrm{cm}^{3}\right) \\
@ 400 \mathrm{kPa} \pm \text { Std. error }\end{array}$ & $\begin{array}{l}\text { Model Displacement }\left(\mathrm{cm}^{3}\right) \\
@ 400 \mathrm{kPa} \pm \text { confidence } \\
\text { interval } \alpha=0.05\end{array}$ \\
\hline 1.51 (low) & $0.10 \%$ (low) & $-\cdots$ & $106 \pm 31 X X$ \\
\hline 1.71(high) & $0.08 \%$ (low) & $23 \pm 2$ & $23 \pm 1$ \\
\hline 1.64 (med) & $0.10 \%$ (low) & $48 \pm 2_{b}^{a}$ & $49 \pm 2$ \\
\hline 1.63 (med) & $6.00 \%$ (med) & $48 \pm 7^{\circ}$ & $43 \pm 2$ \\
\hline 1.67 (high) & $12.00 \%$ (high) & $28 \pm 5_{a}^{b}$ & $28 \pm 1$ \\
\hline
\end{tabular}


Acknowledgments. Thank you to Dr. Gregory Dahle for assistance in data collection and manuscript preparation. Thank you to Walter Joncas for use of shop space, tool assistance and serving as an intellectual sounding board in the final data collection phases. Thanks to $\mathrm{S}$. Williamson and M. Applegate in the machine shop in Rutgers Cook campus for taking rough hand sketches through C.A.D. design and machining-fabrication. Thanks to folks at Novel electronics for several hours of tech support in developing the pad logistics for testing. Funding was provided in part by McIntire Stennis project funds and the John and Eleanor Kuser faculty Scholar endowment.

\section{LITERATURE CITED}

American Society of Testing and Materials. 2005. Standard Method of Sieve Analysis of Fine and Coarse Aggregates, Section 4 Construction Annual Book of ASTM Standards volume 4.08 ASTM Standard C-136-05. ASTM, Philadelphia, PA.

Bartens, J., J.R. Harris, S.D. Day, J.E. Dove, and T.M. Wynn. 2008. Can urban tree roots improve infiltration through compacted subsoils for stormwater management? Journal of Environmental Quality 37:2048-2057.

Bühler, O., P. Kristofferson, and S.U. Larson. 2007. Growth of street trees in Copenhagen with emphasis on the effect of different establishment concepts. Arboriculture \& Urban Forestry 33(5):330-337.

Cheng, Y.P., M.D. Bolton, and Y. Nakata. 2004. Crushing and plastic deformation of soils simulated using DEM. Geotechnique 54(2): 131-141.

Chiroux, R.C., W.A. Foster, Jr., C.E. Johnson, S.A. Shoop, and R.L. Raper. 2004. Three-dimensional finite element analysis of soil interaction with a rigid wheel. Applied mathematics and computation 162(2005):707-722.

Costello, L.R., and K.S. Jones. 2003. Reducing infrastructure damage by tree roots: a compendium of strategies. WCISA, Cohasset, CA.

Das, B.M. 2004. Principles of Foundation Engineering 5E. Brooks/Cole - Thompson Learning. Pacific Grove CA. 743 pp.

Day, S.D., and S.B. Dickinson (Eds.). 2008. Managing stormwater for urban sustainability using trees and structural soils. Virginia Polytechnic Institute and State University, Blacksburg, VA.

Grabosky, J., and N. Bassuk. 2008. Growth of three tree species in designed stone-soil blend under pavement and non-paved lawn in a Brooklyn, New York Streetscape: tenth year data. Arboriculture \& Urban Forestry 34(4):265-266.

Grabosky, J., N. Bassuk, H. van Es. 1996. Testing of structural urban tree soil materials for use under pavement to increase street tree rooting volumes. Journal of Arboriculture 22(6):255-263.

Grabosky, J., T. Haffner, and N. Bassuk. 2009. Measurements of plant available moisture behavior in stone-soil blends for establishing trees and supporting pavement in urban settings. Arboriculture \& Urban Forestry 35(5):271-279.

Grabosky, J.C., E.T. Smiley, and G.A. Dahle. 2011. Observed Symmetry and force of Plantanus $\times$ acerifolia (Ait.) Willd. Roots occurring between foam layers under pavement. Arboriculture \& Urban Forestry 37(1):35-40.

Hewes, L.I. 1942. Grading the roadbed. p. 141-194. In: American highway practice. John Wiley and Sons, New York, NY.

Holtz, R.D., and W.D. Kovacs. 1981. Consolidation and consolidation settlements. p. 283-367. In: An Introduction to Geotechnical Engineering. Prentice Hall, Englewood Cliffs, NJ.

Liingaard, M., A. Augustesen, and P.V. Lade. 2004. Characterization of models for time-dependent behavior in soils. International Journal of Geomechanics 4(3):157-177.
McPherson, E.G., J.R. Simpson, P.J. Peper, Q. Xiao, D.R. Pettinger, and D.R. Hodel. 2001. Tree Guidelines for Inland Empire Communities. Local Government Commission. Sacramento, CA.

National Cooperative Highway Research Program. 1993. AASHTO guide for design of pavement structures 1993. Association of American State and Highway Transportation Officials (AASHTO) Washington D.C. 640 pp.

Rahardjo, H., I.G.B. Indrawan, E.C. Leong, and W.K. Yong. 2008. Effects of coarse-grained material on hydraulic properties and shear strength of top soil. Journal of Engineering Geology 101:165-173.

Scott, K.I., J.R. Simpson, and E.G. McPherson. 1999. Effects of tree cover on parking lot microclimate and vehicle emissions. Journal of Arboriculture 25(3):129-142.

Smiley, T.E., L. Calfee, B. Fraedrich, and E.J. Smiley. 2006. Compaction of Structural Soil and Noncompacted Soils for Trees Surrounded by Pavement. Arboriculture \& Urban Forestry 32(4):164-169.

Swiecki, T.J., and E. Bernhardt. 2001. Guidelines for Developing and Evaluating Tree Ordinances. Accessed May 24, 2010. <http://www. isa-arbor.com/publications/ordinance.aspx $>$. International Society of Arboriculture, Champaign, IL.

Westergaard, H.M. 1926. Stresses in concrete pavement computed by theoretical analysis. Public Roads 7(2):25-35.

\author{
Jason C. Grabosky (corresponding author) \\ Associate Professor \\ Rutgers University \\ Department of Ecology Evolution and Natural Resources \\ 1 College Farm Road \\ New Brunswick, NJ 08901, US \\ grabosky@aesop.rutgers.edu
}

\section{Nenad Gucunski}

Professor

Rutgers University

Department of Civil and Environmental Engineering

Center for Advanced Infrastructure and Transportation

Résumé. Dans le but de modéliser les impacts de la croissance des racines sous une surface pavée composée de différentes couches de fondation, le comportement des différentes composantes doit être défini ou supposé. Étant donné que le comportement des matériaux et du design des différentes couches sous le pavage fonctionne selon des hypothèses de charges appliquées sur le dessus de la surface pavée, il est raisonnable de pouvoir vérifier les hypothèses de comportement au moyen d'une méthode d'essai pour contrôler les charges appliquées sur le dessus par rapport à la croissance d'une racine vivace. Une simulation racinaire a été développée en insufflant de l'eau à une pression définie. Le déplacement des particules de sable en réponse à la pression accrue a été enregistré avec différentes densités de sable appariées avec le degré d'humidité. Des cellules de charge ont enregistré la translation du déplacement du sable en regard d'une charge sur une surface pavée simulée afin de développer un échantillonnage de données d'une ligne de charges qui s'étend sur une large distance avec l'accroissement en distance entre la racine et la surface pavée. Les résultats des expériences en laboratoire ont été comparés à ceux provenant de simulations numériques utilisant des éléments finis afin de développer une meilleure compréhension des mécanismes de génération des charges imputables à la croissance racinaire. Le sable a été modélisé comme un matériau de type Mohr-Coulomb à cette fin. Les résultats numériques sont qualitativement en accord avec les résultats expérimentaux. 
Zusammenfassung. In der Absicht, den Einfluss von Baumwurzelwachstum unter gelegtem Pflaster zu verändern, muss das Verhalten der Komponenten definiert werden. Da das Verhalten der Materialien und das Design der Pflasterverlegung bei der Annahme von der Beanspruchung/ Lasteintrag der Pflasteroberfläche nach unten wirkt, ist es sinnvoll, die Annahmen zum technischen Verhalten mit einer Testmethode für kontrollierte Last von einer jährlich wachsenden Wurzel zu überprüfen. Eine Wurzelsimulation wurde entwickelt, die sich mit Hilfe von Wasser zu einem vorher bekannten Innendruck ausdehnt. Über verschiedene Sanddichtefeuchtigkeitsgrade wurde die Verlagerung von Sand in Antwort auf den wachsenden Druck verfolgt. Lastzellen verfolgten die Übertragung von Sandverlagerung zur Last bei einer bestimmten, simulierten Pflasteroberfläche, um Datanplots zu entwickeln, mit einer Linie der Lastverteilung mit zunehmender Distanz zwischen Wurzel und Pflaster. Die Resultate aus den Laborexperimenten wurden verglichen mit den Resultaten von zahlreichen Simulationen, unter der Anwendung von begrenzten Elementen, die ein besseres Verständnis der Mechanismen der Lastentstehung durch die Wurzeln entwickeln. Der Sand wurde als ein Mohr-
Coulomb Typ Material für diesen Zweck entwickelt. Die zahlreichen Resultate sind qualitativ in Einklang mit den experimentellen Rsultaten.

Resumen. Con el fin de modelar los impactos del crecimiento de las raíces de los árboles bajo el pavimento como un diseño, el comportamiento de los componentes necesarios a ser definidos o asumidos. Debido a que el comportamiento de los materiales y el diseño de secciones de pavimentos trabajan en la presunción de cargas de superficie pavimentada, es razonable revisar el comportamiento desde la ingeniería con un método de prueba para cargas controladas en una raíz de crecimiento perenne. Se desarrolló una simulación de raíz para inflar con agua y conocer la presión de entrada. El desplazamiento de arena en respuesta al incremento de la presión de entrada fue registrado en varios niveles de densidad y humedad. Los resultados de los experimentos de laboratorio fueron comparados a los resultados de simulaciones numéricas usando elementos finitos para desarrollar mejor entendimiento de los mecanismos de generación de carga debida al crecimiento de la raíz. La arena fue modelada como un material tipo Mohr-Coulomb para ese propósito. Los resultados numéricos son cualitativamente acordes con los resultados experimentales. 